\title{
Occurrence, Origin and Transformation Processes of Geogenic Chromium in Soils and Sediments
}

\author{
Maria Chrysochoou $^{1} \cdot$ Elina Theologou ${ }^{2} \cdot$ Nefeli Bompoti $^{1} \cdot$ Dimitris Dermatas $^{2}$. \\ Iraklis Panagiotakis ${ }^{2}$
}

Published online: 22 October 2016

(C) Springer International Publishing AG 2016

\begin{abstract}
Weathering of ultramafic rocks has been linked to the occurrence of elevated concentrations of hexavalent chromium $(\mathrm{Cr}(\mathrm{VI}))$ in soils, sediments, and groundwater. Ultramafic rocks and the derived serpentine soils and sediments are encountered in populated areas around the world and present high $\mathrm{Cr}$ concentrations, with an average of 2200 and $2650 \mathrm{mg} / \mathrm{kg}$ for rocks and soils, respectively. Groundwater concentrations between 0.2 and $180 \mu \mathrm{g} / \mathrm{L}$ have been reported for $\mathrm{Cr}(\mathrm{VI})$ in ultramafic areas, exceeding occasionally the most prevalent drinking water limit of $50 \mu \mathrm{g} / \mathrm{L}$ $\mathrm{Cr}_{\text {tot }}$, the $5 \mu \mathrm{g} / \mathrm{L} \mathrm{Cr}(\mathrm{VI})$ limit established in Italy, and the $10 \mu \mathrm{g} / \mathrm{L} \mathrm{Cr}(\mathrm{VI})$ limit proposed in California. Cr release in groundwater occurs through the dissolution of trivalent chromium $(\mathrm{Cr}(\mathrm{III}))$ from its mineral hosts, followed by sorption of $\mathrm{Cr}(\mathrm{III})$ onto high-valence $\mathrm{Mn}$ oxides and oxidation to $\mathrm{Cr}(\mathrm{VI})$, which desorbs and is mobile at alkaline $\mathrm{pH}$. Recent findings indicate that hydrogen peroxide and birnessite produced on the surface of $\mathrm{Cr}(\mathrm{OH})_{3}$ by heterogeneous oxidation are two additional potential mechanisms. Thus, groundwater
\end{abstract}

This article is part of the Topical Collection on Sediment and Other Pollutions

Electronic supplementary material The online version of this article (doi:10.1007/s40726-016-0044-2) contains supplementary material, which is available to authorized users.

Maria Chrysochoou

maria.chrysochoou@uconn.edu

1 Department of Civil and Environmental Engineering, University of Connecticut, 261 Glenbrook Road, Storrs, CT 06269, USA

2 Department of Water Resources and Environmental Engineering, School of Civil Engineering, National Technical University of Athens, Zografou Campus, 9 Iroon Polytexneiou, Zografou, 15780 Athens, Greece concentrations are controlled by a variety of geoenvironmental factors, including climate, soil mineralogy, $\mathrm{pH}$, organic matter, and others. To provide a basis for the evaluation of $\mathrm{Cr}$ mobility in ultramafic environments, this paper presents an overview of the mineralogy and geochemistry of Cr-rich rocks, sediments, and soils, along with the weathering and geochemical processes that control the fate and transport in the subsurface.

Keywords Hexavalent chromium · Geogenic chromium • Ultramafic rocks $\cdot$ Serpentine soils $\cdot$ Ophiolites

\section{Introduction}

Environmental contamination with hexavalent chromium $(\mathrm{Cr}(\mathrm{VI}))$ has typically been attributed to various anthropogenic activities, including industrial processes such as chromium plating, metal finishing, leather tanning, and paint production [1]. However, the presence of $\mathrm{Cr}(\mathrm{VI})$ in soil and groundwater has also been linked to geogenic processes, namely, weathering of ultramafic rocks in various areas around the world, such as several countries in Europe (Greece, Italy, France, Serbia, Poland), USA, Canada, Brazil, New Caledonia, Cameroon, Taiwan, and others [2-10]. The synergistic effects of both natural and anthropogenic processes may also result in high $\mathrm{Cr}(\mathrm{VI})$ groundwater concentrations. Distinguishing the contribution of each factor is a challenging task and several studies have employed isotope analyses and other geochemical assessments to this end [11-14].

Toxic and carcinogenic effects from industrial $\mathrm{Cr}(\mathrm{VI})$ pollution have been demonstrated since the nineteenth century [15]; however, there have been only limited and recent studies on the effects of naturally occurring concentrations that are below the $50 \mu \mathrm{g} / \mathrm{L}$ WHO limit. The state of California has 
primarily led related efforts, given the prevalence of naturally occurring $\mathrm{Cr}$ in its geological environment $[2,11]$. The $\mathrm{Cr}(\mathrm{VI})$ concentration for de minimis lifetime cancer risk has been determined to be $0.2 \mu \mathrm{g} / \mathrm{L}$ based on mouse studies [16]. As of July 1, 2014 the California Department of Public Health established a $10 \mu \mathrm{g} / \mathrm{L}$ limit for $\mathrm{Cr}(\mathrm{VI})$ in drinking water, a concentration that is often exceeded in water impacted by ophiolitic systems. Italy is the only country that has set the drinking water limit for $\mathrm{Cr}(\mathrm{VI})$ at $5 \mu \mathrm{g} / \mathrm{L}$, which is also often exceeded in Italian ophiolitic regions. In addition to drinking water limits, the European Union mandates the establishment of groundwater quality criteria, which are often based on natural background values. Thus, the geogenic levels of $\mathrm{Cr}(\mathrm{VI})$ in groundwater can have important implications for the allowable uses of water bodies and for necessary remediation measures, which in turn incur cost and resource considerations. Understanding the factors that control geogenic Cr levels is necessary to shape policy and evaluate the economic and health impacts for areas with Cr-rich geologic background. Accordingly, the purpose of this paper is to review the occurrence, origin, and transformations of geogenic $\mathrm{Cr}$ in the environment.

Specifically, the following questions will be examined through a critical synthesis of the relevant literature: (1) what are the anticipated $\mathrm{Cr}$ levels in the ultramafic environments? (2) In what form does Cr naturally occur and what are the relevant transformation processes for its release? (3) What is the influence of local geological and environmental factors on Cr mobility?

\section{Cr Occurrence in Ultramafic Environments}

\section{Surface and Ground Water}

There are several reports of elevated $\mathrm{Cr}(\mathrm{VI})$ concentrations in surface water, groundwater, and soil solutions from ultramafic and mafic geologic backgrounds, occasionally exceeding the World Health Organization (WHO) maximum contaminant level (MCL) for total $\mathrm{Cr}$ in drinking water $(50 \mu \mathrm{g} / \mathrm{L})$. Interestingly, groundwater and surface water data are available for only a subset of the regions with ultramafic geologic background. While some studies report $\mathrm{Cr}(\mathrm{VI})$ and some total $\mathrm{Cr}$ concentrations, it has been demonstrated in several areas that the correlation between the two parameters is very high (typically $\mathrm{R}^{2}>95 \%$ ) and the fraction of $\mathrm{Cr}(\mathrm{VI})$ exceeds $80 \%[7$, $17,18]$, so that either parameter may be used to evaluate $\mathrm{Cr}(\mathrm{VI})$ presence. To facilitate discussion, studies were grouped by country as follows:

a. Italy: In La Spezia, an alpine forested area, $\mathrm{Cr}(\mathrm{VI})$ concentrations in groundwater reached $73 \mu \mathrm{g} / \mathrm{L}$, with 30 out of 58 samples exceeding $5 \mu \mathrm{g} / \mathrm{L}$ [4]. In the southern Appenines, with both forested and agricultural areas, 6 out of 43 springs had $\mathrm{Cr}(\mathrm{VI})>5 \mu \mathrm{g} / \mathrm{L}$, with a maximum of $30 \mu \mathrm{g} / \mathrm{L}$ [19]. Lelli et al. [20] reported median groundwater $\mathrm{Cr}(\mathrm{VI})$ concentrations in the range $1-9 \mu \mathrm{g} / \mathrm{L}$ in selected areas in Tuscany, while individual samples had a maximum of $47 \mu \mathrm{g} / \mathrm{L}$. In Calabria, groundwater concentrations of total $\mathrm{Cr}$ were below $10 \mu \mathrm{g} / \mathrm{L}$ [21].

b. Greece: Several studies have reported groundwater concentrations for Greece, given its ophiolite-rich geologic background; however, the majority of the studies have concentrated in areas with mixed geogenic and anthropogenic influence. Megremi et al. [17] reported an average $\mathrm{Cr}(\mathrm{VI})$ concentration of $25 \mu \mathrm{g} / \mathrm{L}$ in a central Euboea aquifer and attributed concentrations exceeding $50 \mu \mathrm{g} / \mathrm{L}$ (max reported $360 \mu \mathrm{g} / \mathrm{L}$ ) to industrial activities. Several studies have been conducted for the Asopos and Thiva basins, in which there is significant industrial activity in addition to a natural ophiolitic background, causing concentrations $>200 \mu \mathrm{g} / \mathrm{L}$ [22-27]. The only identified study conducted in the agricultural area of Vergina reported $\mathrm{Cr}(\mathrm{VI})$ at $64 \mu \mathrm{g} / \mathrm{L}$ and total $\mathrm{Cr}$ at $90 \mu \mathrm{g} / \mathrm{L}$ due to the geologic background alone [7].

c. USA: Ultramafic rocks in the western USA cover a wide area, ranging from Oregon in the north to the Mojave Desert in the southeastern part of California. Concentrations up to $60 \mu \mathrm{g} / \mathrm{L}$ were reported in the Mojave Desert [18], while the maximum reported concentrations decreased going north, to $30 \mu \mathrm{g} / \mathrm{L}$ in Santa Cruz county [28] and to $22 \mu \mathrm{g} / \mathrm{L}$ in the Cazadero area [2]. However, elevated $\mathrm{Cr}(\mathrm{VI})$ concentrations up to $46 \mu \mathrm{g} / \mathrm{L}$, with $10 \%$ of the groundwater samples exceeding $10 \mu \mathrm{g} / \mathrm{L}$, were reported for groundwater in the Sacramento Valley in the northwestern part of the state $\left[29,30^{\bullet}\right]$. In the vadose zone of these soils, pore water $\mathrm{Cr}(\mathrm{VI})$ concentrations were even higher, ranging from 64 to $180 \mu \mathrm{g} / \mathrm{L}$ [29]. Springs in the Napa Valley north of the Sacramento valley were also found to have up to $90 \mu \mathrm{g} / \mathrm{L}$ total $\mathrm{Cr}[31 \bullet \bullet]$. The Santa Cruz, Napa, and Sacramento valleys are mostly agricultural and suburban areas, while Cazadero is a mountainous region and Mojave has some agricultural activity but is mostly desert.

d. Mexico: The presence of ultramafic rocks in San Juan de Otates, in the agricultural area of León Valley, was linked to $\mathrm{Cr}(\mathrm{VI})$ concentrations in surface water in the range 11$14 \mu \mathrm{g} / \mathrm{L}$ and in groundwater concentrations up to $12 \mu \mathrm{g} / \mathrm{L}$ [32] and cycling between non-detectable and up to $16 \mu \mathrm{g} / \mathrm{L}$ according to more recent data [12].

e. Brazil: This was the only area where naturally occurring $\mathrm{Cr}(\mathrm{VI})$ up to $45 \mu \mathrm{g} / \mathrm{L}$ was reported for groundwater from non-ultramafic parent protoliths, i.e., a sedimentary aquifer consisting of quartzose sandstones. The natural occurrence of aqueous $\mathrm{Cr}(\mathrm{VI})$ was attributed to weathering of diopside grains which contained up to $1.2 \%$ of $\mathrm{Cr}_{2} \mathrm{O}_{3}$ [33]. 
f. New Caledonia: Even though no data related to groundwater or surface water were identified for the ophioliterich New Caledonia region, Becquer et al. [5] reported that phosphate-fertilized soil solutions had $\mathrm{Cr}(\mathrm{VI})$ concentrations between 199 and $555 \mu \mathrm{g} / \mathrm{L}$, with a maximum at $700 \mu \mathrm{g} / \mathrm{L}$. The elevated concentrations were linked to the presence of phosphate, since non-fertilized soil solutions had $\mathrm{Cr}(\mathrm{VI})$ concentrations below $70 \mu \mathrm{g} / \mathrm{L}$.

Based on the above analysis, $\mathrm{Cr}(\mathrm{VI})$ concentrations in ultramafic environments exhibit substantial variability, ranging from non-detectable values $(<1 \mu \mathrm{g} / \mathrm{L})$ to approximately $70 \mu \mathrm{g} / \mathrm{L}$. Despite the differences in the geochemical conditions $(\mathrm{pH}$, oxygen, organic matter, weathering stage, and others) in different areas, it appears that geogenic $\mathrm{Cr}$ in groundwater generally does not exceed $90 \mu \mathrm{g} / \mathrm{L}$ total $\mathrm{Cr}$ or $70 \mu \mathrm{g} / \mathrm{L}$ Cr(VI). Stamatis et al. [26] and Megremi et al. [17] cited an upper limit of $50 \mu \mathrm{g} / \mathrm{L}$ for geogenic $\mathrm{Cr}(\mathrm{VI})$ in Central Greece; however, the criterion for establishing the threshold was not discussed. While concentrations exceeding 70$90 \mu \mathrm{g} / \mathrm{L} \mathrm{Cr}(\mathrm{VI})$ or total $\mathrm{Cr}$ may be globally considered to have at least some anthropogenic origin, the background threshold will vary for individual areas depending on local conditions. Distinguishing the extent of $\mathrm{Cr}(\mathrm{VI})$ plumes in areas with high $\mathrm{Cr}$ (VI) background on the basis of concentration alone is challenging, and the use of alternative methods such as evaluation of isotopes is recommended [11]. Distinguishing between natural geogenic concentrations and anthropogenic contamination is particularly important from the regulatory standpoint, and evaluating trends in background concentrations is critical for public health considerations.

\section{Soils, Sediments, and Rocks}

Naturally occurring $\mathrm{Cr}$ is typically associated with ultramafic igneous and metamorphic rocks, such as peridotites and serpentinites, and their derived soils. In some cases, mafic rocks and their products may also be linked to elevated $\mathrm{Cr}$ concentrations. Figure S1 provides an overview of the rock types encountered in this review, which are distinguished by their chemical and mineralogical composition. Ultramafic rocks are poor in $\mathrm{Si}$ rich in $\mathrm{Mg}$ and are composed of the primary minerals olivine and pyroxene. The process of serpentinization, i.e., hydration at low temperature and pressure, leads to metamorphic rocks called serpentinites, which are composed mainly of the minerals lizardite, antigorite, and chrysotile, also known as asbestos [34]. From these, ultimately serpentine soils and sediments are developed that are enriched in $\mathrm{Cr}$ and other associated elements such as $\mathrm{Co}$ and $\mathrm{Ni}[3,34]$. Some mafic rocks such as gabbro, with higher $\mathrm{Si}$ and lower $\mathrm{Mg}$ concentrations, have minerals that are also associated with ultramafic rocks, including chlorite and amphiboles, and also have higher $\mathrm{Cr}$ contents compared to the global average of $35 \mathrm{mg} / \mathrm{kg}$ in the upper Earth's crust [35].

Accordingly, the $\mathrm{Cr}$ concentrations were evaluated for three groups, as shown in Fig. 1: ultramafic rocks (including igneous and serpentinized rocks), mafic rocks (both igneous and metamorphic), and soils developed in areas with both ultramafic and mafic rocks. While Deschamps et al. [36] provide a comprehensive review on serpentinite rock properties regardless of the geologic setting, this review focused on data available from areas with impacted soils, sediments, and aquifers, i.e., areas with potential human impact. Soils and sediments were grouped in a single category because various pedogenetic processes cause diverse soil and sediment environments with mixed geologic backgrounds. The raw data used to calculate the plots in Fig. 1 are provided in Supplemental Information, along with the descriptive statistics (mean, median, $95 \%$ confidence intervals, variance, etc.). It should be noted here that performing statistical analyses for different types of analytical methods (e.g., X-ray fluorescence versus different types of digestions and ICP-MS) did not yield statistically significant difference in the overall results.

The mean and median values of the $\mathrm{Cr}$ concentration for ultramafic rocks are 2215 and $2261 \mathrm{mg} / \mathrm{kg}$, respectively, close to the $2300 \mathrm{mg} / \mathrm{kg}$ provided by Alloway [35]. The interquartile range $(25-75$ percentiles) is 1750 to $2750 \mathrm{mg} / \mathrm{kg}$. Deschamps et al. [36] reviewed the properties of serpentinite rocks from different protoliths and reported average $\mathrm{Cr}$ concentrations in the range 1734 to $2907 \mathrm{mg} / \mathrm{kg}$. Subducted serpentinites that are typically associated with ophiolite complexes and serpentine soils had average $\mathrm{Cr}$ of $2900 \mathrm{mg} / \mathrm{kg}$ regardless of the protolith; the higher concentration is likely due to the fact that most datasets in the Deschamps et al. [36] analysis were from European ophiolite complexes. Isolating the European studies (Poland, Italy, Greece, and Czech Republic) in this analysis yields an almost identical average concentration of $2844 \mathrm{mg} / \mathrm{kg}$. In terms of other geographic patterns, Californian rocks had all total $\mathrm{Cr}$ concentrations at or below average. In Mexico, a single available study reported much lower $\mathrm{Cr}$ concentrations for several rocks described as serpentinite [32]. Data on $\mathrm{Cr}$ rock concentrations in conjunction with soils in tropical areas was scarce and the few values reported for New Caledonia (2053 mg/kg [37]) and Cameroon (1437 mg/kg [9]) were below average, which is particularly interesting given the very high soil concentrations in these areas, as will be discussed subsequently. Additional datasets for rocks in these areas are available in geologic studies cited by Deschamps et al. [36].

Mafic rocks, for which there is much less data available, have lower mean $(1100 \mathrm{mg} / \mathrm{kg})$ and median $(860 \mathrm{mg} / \mathrm{kg})$ values and the interquartile range is also lower (620$1060 \mathrm{mg} / \mathrm{kg}$ ). However, it is clear that mafic rocks also have the potential to have substantially higher $\mathrm{Cr}$ concentrations compared to the global average. These mafic rocks were 

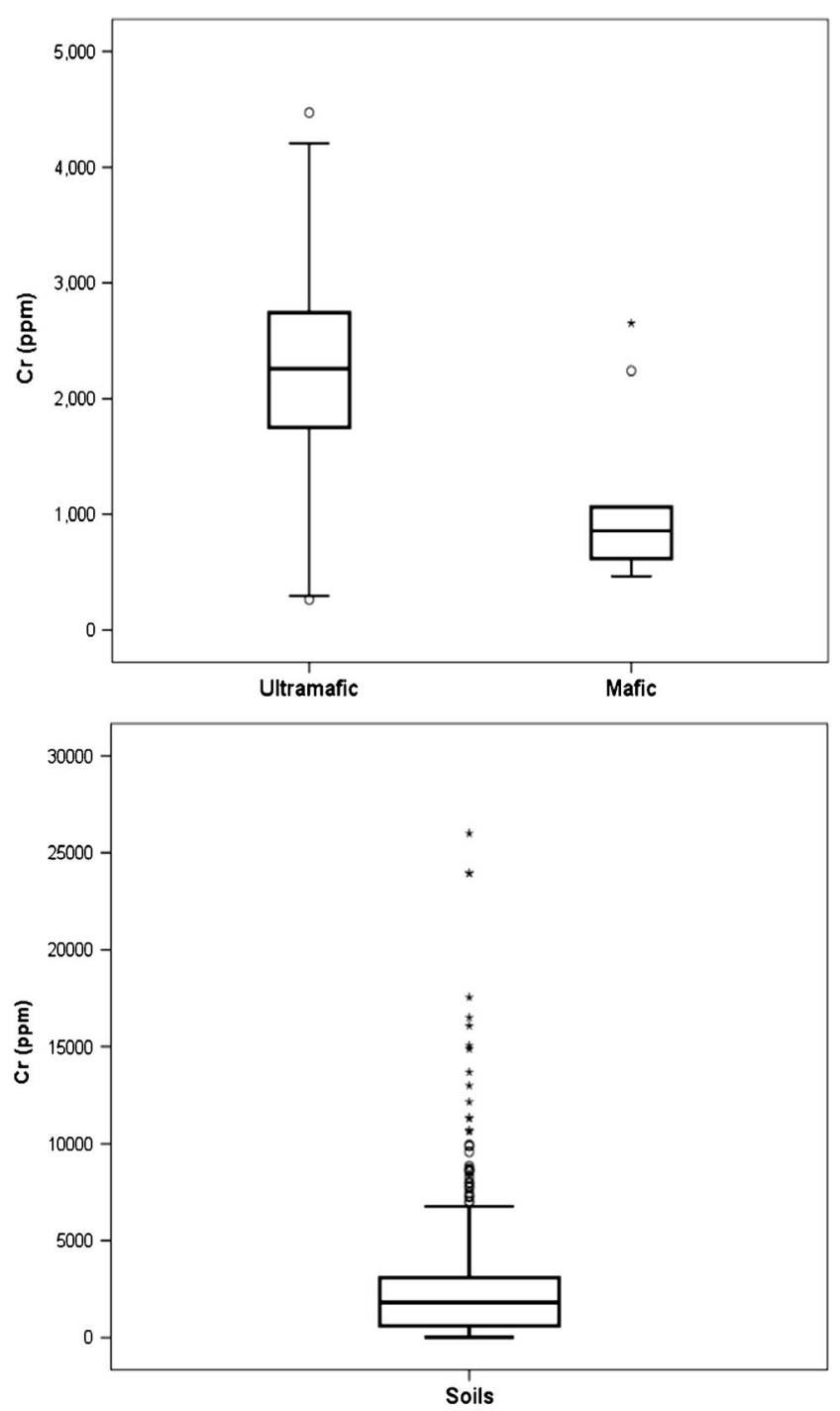

Fig. 1 Boxplots of total $\mathrm{Cr}$ concentrations in ultramafic and mafic rocks (top) and soils and sediments (bottom). Raw data are available in Supplemental Information

encountered in Italy [38], in Poland [39], and in the Mojave Desert [40], and in all cases, they were present in association with ophiolite complexes. Finally, one case was reported in Brazil, in which diopside (pyroxene mineral) grains were present in a quartzite sandstone environment and resulted in $\mathrm{Cr}$ concentrations in the range $129-336 \mathrm{mg} / \mathrm{kg}$ [41] (these were not included in any statistics).

Soils and sediments presented a wider distribution of concentrations, which reflects the greater variability caused by various pedogenetic processes and contribution of different soil types mixed with the original weathering products of ultramafic rocks. The mean concentration was $2655 \mathrm{mg} / \mathrm{kg}$ and median $1810 \mathrm{mg} / \mathrm{kg}$, with the interquartile range between 609 and $3077 \mathrm{mg} / \mathrm{kg}$. Extreme outliers exceeding 10,500 mg/kg (three times higher than the interquartile range) were identified in lateritic soils from tropical areas, including New Caledonia [5, 41], Sri Lanka [42, 43], Brazil [8], and Africa
$[9,44]$. Only one extreme outlier was identified in a temperate climate in Vergina, Greece, which also occurred in 100-m deep ophiolitic sediments [7]. Moderate outliers exceeding $6800 \mathrm{mg} / \mathrm{kg}$ (1.5 times higher than the interquartile range) were present in France [45] and Greece [7], in addition to tropical areas. The substantial accumulation of $\mathrm{Cr}$ in soils in these areas compared to the parent rocks is related to the accelerating weathering that causes leaching of mobile elements such as $\mathrm{Mg}$, the primary element in ultramafic rocks, leaving behind less mobile elements such as $\mathrm{Fe}$ and $\mathrm{Cr}$, a wellestablished process in several studies [5, 37, 45].

Weathering processes are also responsible for the vertical profile or $\mathrm{Cr}$ with depth. Oze et al. [2] summarized $\mathrm{Cr}$ profiles with depth down to $5 \mathrm{~m}$ in serpentine soils in the USA and Canada, and all showed a decreasing trend. Additional soil and sediment profiles across the world are shown in Figure S1. In New Caledonia, Brazil, and France, the trends were also decreasing with depth. This is attributed to mineral weathering processes that result in a net accumulation of immobile elements near the surface, as also observed for Fe and Al. This is also linked to the fact that all reported studies refer to relatively shallow soils, with the underlying bedrock at 1.5 2-m depth. Trends change for soils sampled from slopes and for very deep lateritic sediments, with only a handful of available studies. Dzemua et al. [9] reported Cr concentrations down to $20-\mathrm{m}$ depth in a lateritic regolith developed on serpentinite from Cameroon; Trolard et al. [44] studied laterites developed on peridotite in Burundi down to $40 \mathrm{~m}$; and Dermatas et al. [7] reported $\mathrm{Cr}$ concentrations down to a 93-m depth in Vergina, Greece. While Trolard et al. [44] present too few data points to identify specific trends, both Dzemua et al. [9] and Dermatas et al. [7] had similar trends: Cr concentrations decreased in the first 5-7-m depth, followed by a continuous increase up to $20 \mathrm{~m}$ in the Cameroon sediment and an overall, but not continuous, increase down to $100 \mathrm{~m}$ in the Greek sediment. Pedogenetic and weathering processes that explain trends in shallow soil layers are likely to be quite different in very deep sediments such as laterites. Furthermore, other factors, such as differences in mineralogical and chemical composition of the parent ultramafic rock and the weathering stage/age of the evolved lateritic soil developed on ultramafic rock, are critical factors affecting the worldwide encountered heterogeneities.

The distribution of $\mathrm{Cr}$ may also vary when examining the longitudinal behavior (along a toposequence) of these elements. Specifically, in Taiwan, lower concentrations were found on the summit and shoulder positions in contrast to higher concentrations on the backslope and footslope positions of a serpentinitic hill [46]. However, these trends were not similar in slopes studied in Italy [47] and Brazil [8], so that no generalized trend may be inferred for sloped soils. The vertical and lateral trends in $\mathrm{Cr}$ concentrations are driven by the mineralogy and the dominant weathering processes in 
each locality, which are influenced by climate and topography. Accordingly, speciation and mineralogy will be discussed in the following sections.

\section{Mineralogy and Speciation}

\section{Chromium (III) Speciation}

Most of the $\mathrm{Cr}$ (III) minerals contain $\mathrm{Cr}^{3+}$ ions in octahedral coordination with oxygen. The fact that the octahedral radius of $\mathrm{Cr}(\mathrm{III}), 0.615 \AA$, lies between the values of $\mathrm{Al}^{3+}(0.53 \AA)$, $\mathrm{Fe}^{3+}(0.645 \AA), \mathrm{Ti}^{4+}(0.68 \AA)$, and $\mathrm{Mg}^{2+}(0.72 \AA)$ creates several isostructural possibilities for $\mathrm{Cr}(\mathrm{III})$ compounds and minerals with corresponding $\mathrm{Al}$ and $\mathrm{Fe}(\mathrm{III})$ phases, as well as substitutions between $\mathrm{Cr}^{3+}$ ions and $\mathrm{Al}, \mathrm{Fe}, \mathrm{Ti}$, and $\mathrm{Mg}$ in octahedral sites. As such, there are several Cr-bearing hosts in ultramafic rocks and serpentine soils and their relative predominance depends on the weathering stage of the rock, sediment, or soil. Figure 2 provides an overview of the mineral groups encountered in rocks and soils/sediments in various weathering stages, while Table S3 contains detailed information about minerals and their chemical formulas. Table S4 summarizes the $\mathrm{Cr}$ host minerals reported in various studies worldwide.

The primary sources of $\mathrm{Cr}$ in rocks are chromite and $\mathrm{Cr}$ magnetite, as well as other mixed-( $\mathrm{Al}, \mathrm{Mg}, \mathrm{Fe}, \mathrm{Cr})$ composition spinels $[2,5,36,46]$. Chromite is typically not pure $\mathrm{FeCr}_{2} \mathrm{O}_{4}$ [2] but contains high levels of $\mathrm{Cr}\left(>35 \% \mathrm{Cr}_{2} \mathrm{O}_{3}\right.$ in the majority of the data), while Cr-magnetite typically hosts less than $15 \% \mathrm{Cr}_{2} \mathrm{O}_{3}$ in its structure (Table S4). The $\mathrm{Cr}$ content of rock-forming spinels reflects the origin of the parent rock, with high $\mathrm{Cr}$ values reflecting origin from subduction zones, while low $\mathrm{Cr}$ content is indicative of abyssal origin [36]. The \#Cr $(\mathrm{Cr} /(\mathrm{Cr}+\mathrm{Al}))$ is often used to differentiate between different types of serpentinite rocks [36]. Chromite grains often exhibit a characteristic zonation, in which an $\mathrm{Mg}-$ $\mathrm{Al}-\mathrm{Cr}$ rich core is surrounded by a Fe-rich rim that consists primarily of ferrichromite and ultimately magnetite $[32,37$, 48-50]. The significance of this chemical modification is that it can increase labile $\mathrm{Cr}$ [32].

Cr-bearing spinels persist to some degree in soils and sediments. The contribution of spinels to the total $\mathrm{Cr}$ content of soils is usually difficult to establish due to a lack in quantitative data for the abundance of either the amount of spinels or their $\mathrm{Cr}$ content. Morrison et al. [49] reported a spinel content (including magnetite and chromite) between 4 and $7 \%$ for serpentine soils in California, and the chromite $\mathrm{Cr}$ content was $25-30 \%$, while magnetite rims had no measurable $\mathrm{Cr}$. One percent of chromite with $30 \% \mathrm{Cr}$ content corresponds to $3000 \mathrm{mg} / \mathrm{kg}$ total $\mathrm{Cr}$, while the total $\mathrm{Cr}$ of the soil was reported at $2000 \mathrm{mg} / \mathrm{kg}$, which means that almost all $\mathrm{Cr}$ could be accounted for by a Cr-rich spinel. Taking the average $\mathrm{Cr}_{2} \mathrm{O}_{3}$ concentrations reported in all individual studies (Figure S3), chromite grains contain $38 \% \mathrm{Cr}_{2} \mathrm{O}_{3}$ in rocks and $43 \%$ in soils which corresponds to $2600 \mathrm{mg} / \mathrm{kg} \mathrm{Cr}$ for $1 \%$ of chromite in rocks and $2940 \mathrm{mg} / \mathrm{kg} \mathrm{Cr}$ in soils. Comparing these values to the total $\mathrm{Cr}$ concentrations found in most rocks, soils, and sediments, it follows that $\mathrm{Cr}$-bearing spinels likely account for the vast majority of $\mathrm{Cr}$ mass.

Typically, $\mathrm{Cr}$ concentrations are enriched in the sand-size fraction which corresponds to the size of most chromite grains inherited from the serpentinite [36, 51]. Comparing the chromite grain concentrations between an ultramafic bedrock and the derived soil, the soil chromite grains contained significantly higher concentrations of $\mathrm{Cr}$ in two regions with available data, Greece and California [51, 52]. Kelepertzis et al. [52] and Fandeur et al. [37] observed an accompanying reduction in the $\mathrm{Al}$ content of the relict chromite grains in soil compared to bedrock, which is likely due to incongruent dissolution that preferentially releases $\mathrm{Al}^{3+}$ vs. $\mathrm{Cr}^{3+}$ into solution. Magnetite presented the same trend of $\mathrm{Cr}$ enrichment in the soil vs. the rock in California [51], but this was not the case in the rock and soil from Poland [6].

Of the remaining rock-forming minerals (groups 1 and 2 in Fig. 2), pyroxenes and chlorite are the most important $\mathrm{Cr}$ hosts. Pyroxenes, mostly enstatite and augite, incorporate $0.1-1.5 \%$ of $\mathrm{Cr}_{2} \mathrm{O}_{3}$ in their structure in rock studies from several localities (Greece, Czech Republic, Poland, California, New Caledonia). Pyroxenes are generally depleted from the parent rock during the serpentinization process and thus occur in soils and sediments only as trace phases in isolated cases $[52,53]$. Chlorite abundance has been reported at $15 \%$ in rock [51] and between $2 \%$ [49] in serpentine soil and $9 \%$ in deep serpentine sediment [7]. Its $\mathrm{Cr}_{2} \mathrm{O}_{3}$ content in soils is typically in the range of $0.4-1 \%$, so that $1 \%$ chlorite may account for approximately $40-100 \mathrm{mg} / \mathrm{kg}$ total $\mathrm{Cr}$.

Serpentine minerals, which are the major phases in serpentine rocks (up to $70 \%$ [51]) and are still present in substantial amounts in serpentine soils (e.g., 34-37\% in California [49]), typically contain less than $1 \% \mathrm{Cr}_{2} \mathrm{O}_{3}$ in their structure. Oze et al. [51] found no $\mathrm{Cr}$ in serpentine minerals in Californian serpentinite, while Fandeur et al. [37] determined that lizardite was the primary $\mathrm{Cr}$-bearing phase in New Caledonia. While the $\mathrm{Cr}$ content of serpentine minerals may be low, their abundance renders them important phases for $\mathrm{Cr}$ release on a mass basis. For example, $30 \%$ of lizardite with $0.5 \% \mathrm{Cr}_{2} \mathrm{O}_{3}$ in its structure can account for $1000 \mathrm{mg} / \mathrm{kg}$ of total $\mathrm{Cr}$ in the soil. Assessing a true average $\mathrm{Cr}$ content in a large serpentine mass using microscopy methods is, however, a challenge, as typically, studies present results of isolated grains and point analyses.

Garnets and epidotes, which are typically minor phases in ultramafic rocks, have the capacity to bind high amounts of $\mathrm{Cr}$ (up to $29 \% \mathrm{Cr}_{2} \mathrm{O}_{3}$ for garnets, and $19 \%$ for epidotes). However, their low abundance renders them secondary hosts in terms of the overall mass retained in the rock. Other less 
Fig. 2 Overview of the most important minerals found within ultramafic rocks, serpentinites, and the derived serpentine soils
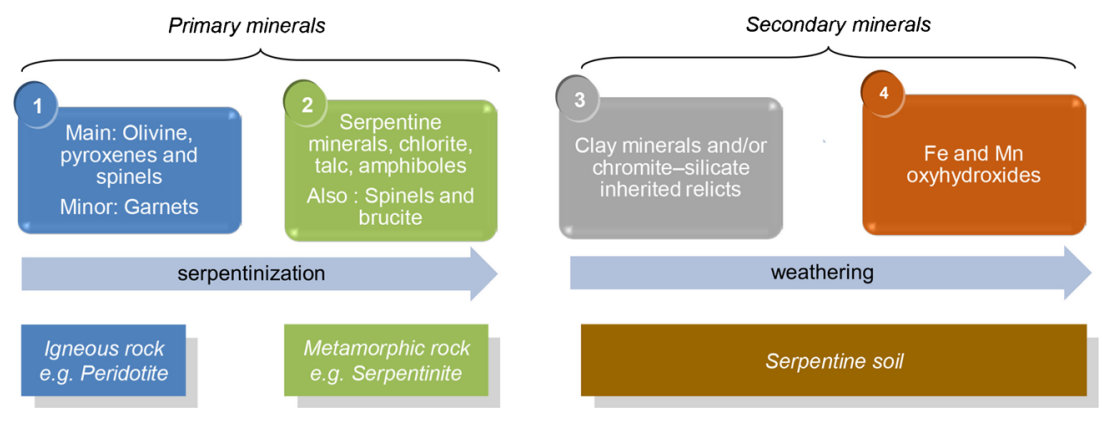

important $\mathrm{Cr}$ hosts in rocks are amphiboles, such as actinolite and tremolite [6, 52, 54], micas [2, 6], talc [5], and olivines [4, $6,32]$. Silicates overall have been found to account for less than $10 \%$ of the total $\mathrm{Cr}$ mass in soil [51].

$\mathrm{Fe}(\mathrm{III})$-oxides and (oxy)hydroxides such as goethite, hematite, and maghemite, either well-crystallized or amorphous, are generally considered as important hosts for $\mathrm{Cr}$ in serpentine soils $[2,37,52,54]$. These can provide surface sites (via sorption) or structural sites (via isomorphic substitution) for $\mathrm{Cr}$ (III) sequestration. Goethite and hematite were found to be the main $\mathrm{Cr}$ scavengers in soils derived from ultrabasic rocks in New Caledonia, with $40 \%$ of the total available Cr included in goethite from Ferralsols [5] and between 67 and $75 \%$ of the total $\mathrm{Cr}$ in goethite and hematite from Oxisols [37]. In both cases, while the $\mathrm{Cr}_{2} \mathrm{O}_{3}$ content was relatively low $(\sim 2 \%)$, these highly weathered soils had high contents of Fe oxides. To a lesser extent, Cr-bearing goethite was found to accommodate $\mathrm{Cr}\left(\sim 1.70\right.$ wt.\% $\left.\mathrm{Cr}_{2} \mathrm{O}_{3}\right)$ in sediments and soils influenced from ultramafic parent rocks (i.e., peridotite) in Greece [55]. Soils developed from serpentinites and/or partially serpentinized peridotites from Poland had $\mathrm{Cr}$ in a mixture phase consisting of oxyhydroxides and clay minerals $(0.14$ wt.\% $\mathrm{Cr}_{2} \mathrm{O}_{3}$ ) [13]. Finally, Cr-bearing ferrihydrite was identified in California soils [49].

Secondary phyllosilicates and in particular clays (such as smectite and vermiculite) can trap $\mathrm{Cr}$ (III) either via isomorphic substitution into their crystal lattices or via sorption onto their surfaces [2]. These are typically found in soils in temperate climates, as they are the weathering products of primary silicates and specifically chlorite and serpentine [45, 56], while in tropical climates complete leaching of $\mathrm{Mg}$ leads to direct formation of metal oxides [6]. A sequence between different secondary clay minerals and oxides along soil profiles developed from serpentinites from the bottom (lower profile/horizon) toward the top (surface profile/horizon) under temperate climate can be expressed as Mg-clays $\rightarrow$ Fe-clays $\rightarrow$ Al-clays $\rightarrow$ Fe and Al (oxy-hydr)oxides [56]. Kierczak et al. [6] and Caillaud et al. [56] associated drainage conditions and thickness of serpentine soils with clay mineralogy. Well-drained soils are shallow soils with very thin (mm thick) developed $\mathrm{C}$ horizon (saprock), containing stable vermiculite, whereas poorly drained soils are thicker soils with well- developed (meter thick) saprock and saprolite containing smectites. Smectite is the ultimate weathering product under impeded, poorly drained landscape positions in temperate [57, 58] or humid tropical climates [59]. From the above analysis, it follows that the significance of clays in hosting $\mathrm{Cr}$ on a mass basis depends on the weathering stage of the soil or sediment. For example, Caillaud et al. [45] reported that vermiculite was the most significant $\mathrm{Cr}$ host in the uppermost weathered $\mathrm{B}$ horizon in French soil, while spinels and chlorite persisted and contained most $\mathrm{Cr}$ in the lower $\mathrm{C}$ horizon and in the bedrock.

In Taiwan, soils in more advanced development stage at the footslope of a toposequence had more $\mathrm{Cr}$ bound in clays, especially vermiculite, and this was also associated with higher availability for leaching [60].

More exotic species that can accumulate $\mathrm{Cr}$ (III) include sulfides and alkaline oxides and sulfates. In particular, sulfides from ultramafic rocks from Mexico were found to contain less than 1 wt.\% of $\mathrm{Cr}$ [32]. Also, at a rock complex at the Nabi Musa locality (Judean Desert, Israel), where processes like high and ultrahigh temperature combustion of metamorphic rocks and low-temperature hydrothermalism have resulted in a hyperalkaline environment $(\mathrm{pH}>11), \mathrm{Cr}$ (III) was found in bentorite, a $\mathrm{Cr}(\mathrm{III})$-rich variety of ettringite $\left[\mathrm{Ca}_{6} \mathrm{Al}_{2}\left(\mathrm{SO}_{4}\right)_{3}(\mathrm{OH})_{12} \cdot 26\left(\mathrm{H}_{2} \mathrm{O}\right)\right]$, and in uncommon oxides such as brownmillerite $\left[\mathrm{Ca}_{2}\left(\mathrm{Al}, \mathrm{Fe}^{3+}\right)_{2} \mathrm{O}_{5}\right]$ and perovskite $\left(\mathrm{CaTiO}_{3}\right)$ [61].

\section{Chromium (VI) Speciation}

Chromate minerals are extremely rare in nature and their occurrence has not, thus far, been linked to areas with geogenic $\mathrm{Cr}$ exhibiting elevated $\mathrm{Cr}(\mathrm{VI})$ concentrations in the aqueous phase. The average $\mathrm{Cr}-\mathrm{O}$ distance in chromate $(\approx 1.65 \AA)$ is within the range of $\mathrm{S}-\mathrm{O}$ distance in sulfate $(1.46 \AA), \mathrm{P}-\mathrm{O}$ distance in phosphate $(\approx 1.52 \AA)$, and As-O distance in arsenate $(\approx 1.68 \AA)$, so that solid solutions are found between these oxyanions in secondary minerals [62]. For example, crocoite $\left(\mathrm{PbCrO}_{4}\right)$ is extremely rare in serpentinites and the occurrence of this mineral is mainly limited to specific localities such as in Australia, Tasmania, and the Urals [2] and references therein]. Chromatite $\left(\mathrm{CaCrO}_{4}\right)$ has been identified in Jordan as lemon- 
yellow precipitates within fractures of Upper Cretaceous limestones and marls, co-occurring with gypsum [63] and at the Nabi Musa locality (Judean Desert, Israel) where hashemite $\left(\mathrm{BaCrO}_{4}\right)$ occurred in solid solution with barite $\left(\mathrm{BaSO}_{4}\right)$ [61]. In general, $\mathrm{Cr}(\mathrm{VI})$ occurrence and mobility in serpentine environments is mostly affected by redox reactions and sorption, instead of precipitation, and these will be considered next.

\section{Transformation and Release Processes}

$\mathrm{Cr}$ may be transported in the subsurface either through physical weathering and transport of the rock and soil constituents [64] or through chemical weathering and transport in the aqueous phase. As previously discussed, almost all minerals (e.g., spinels such as chromite and $\mathrm{Cr}$-magnetite, Fe-oxides, pyroxenes, chlorites, clays, serpentines, and various silicates) may contain variable amounts of $\mathrm{Cr}(\mathrm{III})$, while $\mathrm{Cr}(\mathrm{VI})$ is hardly ever present in the solid phase. Conversely, transport of $\mathrm{Cr}$ in the aqueous phase occurs almost exclusively in the hexavalent form, given the low mobility of $\mathrm{Cr}$ (III). Thus, mobility of $\mathrm{Cr}$ in ultramafic systems depends primarily on two subsequent reactions: release of $\mathrm{Cr}$ (III) into solution due to mineral weathering and oxidation of $\mathrm{Cr}(\mathrm{III})$ to $\mathrm{Cr}(\mathrm{VI})$. Following these reactions, $\mathrm{Cr}(\mathrm{VI})$ may also react with the solid phase either via sorption or via re-reduction by naturally occurring reductants (mostly ferrous iron and sulfide). These processes are illustrated in Fig. 3, assuming that chromite is the primary $\mathrm{Cr}(\mathrm{III})$-bearing phase in the soil or sediment and which is typically the most important $\mathrm{Cr}(\mathrm{III})$ host on a mass basis. However, all $\mathrm{Cr}$-bearing minerals are subject to chemical weathering and release of $\mathrm{Cr}(\mathrm{III})$ into solution. Even minerals with lower $\mathrm{Cr}$ concentrations compared to chromite, e.g., chlorite, pyroxenes, and clay minerals, may be substantial sources of $\mathrm{Cr}$ to soil solution given their relative susceptibility to weathering and dissolution [51].

The relative stability of minerals encountered in ultramafic and serpentine soil may be summarized in the following sequence (with increasing resistance to weathering): olivine $<$ pyroxenes $<$ serpentine $<$ chlorite $<$ talc $<$ Fe-oxides (hematite, goethite) + spinels (chromite, magnetite) $[2,52,55,56]$. From this weathering sequence, it can be concluded that $\mathrm{Cr}-$ spinels (chromite and $\mathrm{Cr}$-magnetite) are the most recalcitrant minerals and indeed, the bioavailability of $\mathrm{Cr}$ is typically very low, in the order of $1 \%$ of the total concentration [2].

Weathering of primary and secondary minerals is influenced by several factors, such as $\mathrm{pH}$, presence of organic acids, and microbial activity [47, 65]. Kierczak et al. [66] observed that the relationship of these parameters and $\mathrm{Cr}$ mobility was more pronounced in soils exhibiting advanced serpentinization. The effect of soil organic acids such as oxalic and citric acid to metal $(\mathrm{Cr}, \mathrm{Mg}, \mathrm{Fe}, \mathrm{Ni}$, and $\mathrm{Co})$ leaching and enhancing of the dissolution of the Cr-bearing phases is pronounced. Oxalic acid produced from a lichen may also accelerate mineral weathering. The growth of Lecanora atra (lichen) on chrysotile in a serpentinitic rock formed a crust, where accelerated decomposition of chrysotile was observed, presumably with oxalic acid as the active agent [67].

Another influencing factor is agricultural activity and specifically the use of ammonium fertilizers. Mills et al. [29, 68] observed higher $\mathrm{Cr}(\mathrm{VI})$ concentrations in surficial soil compared to deeper layers and attributed this phenomenon to the addition of ammonium fertilizers to the soil. Nitrification (oxidation of $\mathrm{NH}_{4}{ }^{+}$to $\mathrm{NO}_{3}{ }^{-}$) results in production of $\mathrm{H}^{+}$and soil acidification, which favors the increased dissolution of $\mathrm{Cr}(\mathrm{III})$, which is the limiting step for oxidation and production of $\mathrm{Cr}(\mathrm{VI})$ [29]. Becquer et al. [5] also observed increased aqueous $\mathrm{Cr}(\mathrm{VI})$ concentrations in the presence of phosphate fertilizers, in which case the mechanism was most likely related to increased chromate desorption and not enhanced $\mathrm{Cr}$ (III) release. However, the relative contribution of these mechanisms have been insufficiently studied and additional research is required to understand the rates of geogenic $\mathrm{Cr}$ release.

The release of $\mathrm{Cr}$ (III) in solution results in almost immediate immobilization due to its low solubility. If the conditions are conducive, it may be included in secondary phases, such as clays and $\mathrm{Fe}$ oxyhydroxides. A simple geochemical model using Visual Minteq [69] indicates that the solubility of Cr(III) with respect to $\mathrm{Cr}(\mathrm{OH})_{3}$ is approximately $5 \mu \mathrm{g} / \mathrm{L}$ in the $\mathrm{pH}$ range $7-10.5$ and increases rapidly to $40 \mu \mathrm{g} / \mathrm{L}$ at $\mathrm{pH} 6$ and $100 \mu \mathrm{g} / \mathrm{L}$ (the initial assumed concentration) at $\mathrm{pH}$ 5.5. Observed concentrations of $\mathrm{Cr}$ (III) in weakly alkaline natural waters have typically been well below solubility, in the range $<0.01$ to $0.1 \mu \mathrm{g} / \mathrm{L}$ and one occurrence at $70 \mu \mathrm{g} / \mathrm{L}$, indicating that its concentration is likely controlled by lower solubility minerals in these ultramafic environments [70].

There are very few oxidants for $\mathrm{Cr}$ at room temperature and Mn-oxides have been considered the primary oxidants in soil and rock environments [71]. Particularly, mixed-high-valence $\mathrm{Mn}(\mathrm{IV} / \mathrm{III})$-oxides, such as birnessite [72], pyrolusite, and cryptomelane [73] as well as hausmannite $\left(\mathrm{Mn}^{2+} \mathrm{Mn}^{3+}{ }_{2} \mathrm{O}_{4}\right)$ and manganite $\left(\mathrm{Mn}^{3+} \mathrm{OOH}\right)$ [74], are all potential $\mathrm{Cr}$ oxidants and typically present as coatings on soil/rock grains (Fig. 3). Manceau and Charlet [75] showed that $\mathrm{Cr}$ (III) oxidation occurs through electron transfer in the solid phase, once $\mathrm{Cr}$ (III) has been adsorbed to the Mn oxide surface. Oze et al. [76] studied the interaction between chromite and birnessite and provided a $\mathrm{pH}$-dependent expression for $\mathrm{Cr}(\mathrm{VI})$ production, with decreasing $\mathrm{pH}$ resulting in increased $\mathrm{Cr}(\mathrm{VI})$ production. Incubation experiments with natural soils yielded $\mathrm{Cr}(\mathrm{VI})$ production of $1.3 \mathrm{nM} / \mathrm{h}$ at $\mathrm{pH}$ 5. Rajapaksha et al. [77] recently studied the interaction between $\mathrm{Cr}(\mathrm{III})$-muscovite and birnessite and found that up to $380 \mathrm{nM} / \mathrm{h}$ (or $48 \mathrm{nmol} / \mathrm{g} * \mathrm{~h}$ ) of $\mathrm{Cr}(\mathrm{VI})$ could be produced by a $8 \mathrm{~g} / \mathrm{L}$ fuchsite (Cr-bearing muscovite) suspension at $\mathrm{pH} 3$; this rate decreased by one order of magnitude as the $\mathrm{pH}$ increased to 5 and two orders of magnitude at $\mathrm{pH} 8$. At pH 5, the observed rate was $23 \mathrm{nM} / \mathrm{h}$, 
Fig. 3 Schematic of primary $\mathrm{Cr}$ reactions in an ultramafic system considering chromite as the primary mineral host

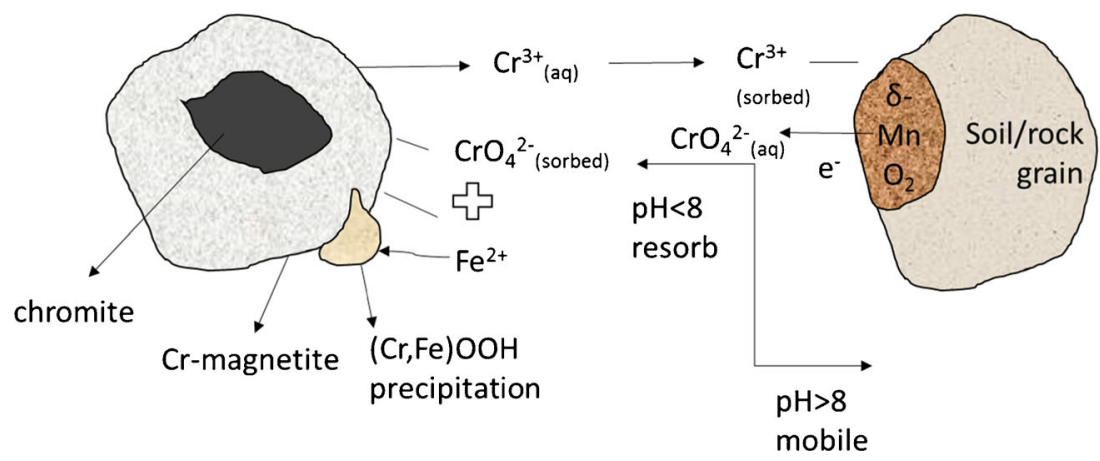

i.e., ten times faster compared to the natural soil by Oze et al. [76]. This is expected, as the concentration of active Mnoxides and the dissolution of $\mathrm{Cr}$ (III) are expected to be lower in a natural soil compared to a controlled system, as well as to the lower expected solubility (due to higher weathering recalcitrance) of chromite compared to a phyllosilicate mineral such as muscovite; still, the values are relatively comparable. Saputro et al. [70] studied the release of $\mathrm{Cr}(\mathrm{VI})$ from natural serpentinite and reported $11.5 \mathrm{nmol} / \mathrm{gh}$ at $\mathrm{pH} \mathrm{4-6}$ and $60 \mathrm{nmol} / \mathrm{gh}$ at $\mathrm{pH} \mathrm{8-10.} \mathrm{Thus,} \mathrm{while} \mathrm{the} \mathrm{values} \mathrm{are} \mathrm{relatively}$ comparable to Rajapashka et al. [77], the pH trend was opposite. This was attributed to the presence of natural reductants such as humic acids, as well as $\mathrm{Cr}$ (III) complexation by organic matter [70]. Similarly, Rajapaksha et al. [77] reported that the presence of humic matter resulted in inhibition of the oxidation reaction due to the formation of soluble $\mathrm{Cr}$ (III) organic complexes that presumably inhibits sorption and electron transfer from the Mn oxide surface. However, $\mathrm{Cr}$ (III) complexation with organic matter increases with $\mathrm{pH}$ [78], so that the $\mathrm{pH}$ trend observed by Saputro [70] cannot be explained by this phenomenon alone.

There is only one study that has recently reported on the heterogeneous reaction between solid $\mathrm{Cr}(\mathrm{OH}) 3(\mathrm{~s})$ and $\mathrm{Mn}$ oxides. Specifically, Namgung et al. [79•] reported that the oxidation of dissolved $\mathrm{Mn}(\mathrm{II})$ by oxygen was catalyzed on the surface of $\mathrm{Cr}(\mathrm{OH})_{3}$, which was in turn oxidized by the produced high-valence Mn oxide, a birnessite-like product. The production of $\mathrm{Cr}(\mathrm{VI})$ was highest at $\mathrm{pH} 9$ and reached $8 \mu \mathrm{M}$ or $400 \mu \mathrm{g} / \mathrm{L}$ within 20 days of reaction. The fact that $\mathrm{Cr}(\mathrm{VI})$ production increased as the $\mathrm{pH}$ increased from 7 to 9 indicates that oxidation likely occurred through a solid-solid reaction, given that $\mathrm{Cr}(\mathrm{III})$ solubility with respect to $\mathrm{Cr}(\mathrm{OH})_{3}$ decreases between $\mathrm{pH} 7$ and 9 and starts increasing again above pH 9.5-10. Thus, this mechanism may be important for geogenic soils with $\mathrm{Mn}(\mathrm{II})$ present in solution and also explain the $\mathrm{pH}$ trends observed by Saputro [70].

Other potential oxidants for $\mathrm{Cr}$ (III) in natural waters include dissolved oxygen (DO) and peroxide $\left(\mathrm{H}_{2} \mathrm{O}_{2}\right)$. Rai et al. [80] found that DO oxidizes $\mathrm{Cr}$ (III) into $\mathrm{Cr}(\mathrm{VI})$, but the rate of oxidation at room temperature is very slow and enables $\mathrm{Cr}$ (III) to be involved in faster concurrent reactions (sorption or precipitation). Therefore, the oxidation of $\mathrm{Cr}(\mathrm{III})$ by DO is unlikely in soils. In another study, Eary and Rai [73] reported no oxidation in $10^{-4.72} \mathrm{M} \mathrm{Cr}$ (III) solutions that were saturated with DO at $27{ }^{\circ} \mathrm{C}$ after as long as 24 days. Fendorf and Zazoski [72] found that small amounts of $\mathrm{Cr}$ are oxidized by $\mathrm{DO}$ at $\mathrm{pH}$ values greater than 9 , but these conditions are uncommon in soil or water environments. Overall, it appears that the rate of this reaction is sufficiently slow in natural waters that it is not responsible for the higher levels of $\mathrm{Cr}(\mathrm{VI})$ observed in groundwater. Most recently, Oze et al. [81 • ] reported that $\mathrm{H}_{2} \mathrm{O}_{2}$ is a viable oxidant for $\mathrm{Cr}$ (III) in ultramafic environments, even in the absence of oxygen, utilizing both laboratory tests and field observations. This study alters the currently accepted paradigm of Mn-induced oxidation and the relative contribution of each mechanism should be further explored.

The fate of $\mathrm{Cr}(\mathrm{VI})$ produced by oxidation is determined by sorption and reduction processes. Sorption is regulated by the presence of iron oxyhydroxides, which are the most common sorbents for $\mathrm{Cr}(\mathrm{VI})$ [82], and by groundwater $\mathrm{pH}$. Izbicki et al. [11] observed $\mathrm{Cr}(\mathrm{VI})$ concentrations above $5 \mu \mathrm{g} / \mathrm{L}$ only when the $\mathrm{pH}$ increased above 7.5 in the mafic environment of the Mojave Desert, and this was attributed to desorption from the solid when the $\mathrm{pH}$ is increased above 8 . In general, oxic and alkaline conditions are necessary for enhanced mobility of $\mathrm{Cr}(\mathrm{VI})$, as these are unfavorable for sorption and reduction reactions that result in $\mathrm{Cr}$ immobilization.

If naturally occurring reductants are present, then $\mathrm{Cr}(\mathrm{VI})$ will be reduced and reprecipitate as $\mathrm{Cr}$ (III). If reduction occurs away from the original source of $\mathrm{Cr}(\mathrm{VI})$, it is possible to evaluate whether reduction has occurred through the evaluation of Cr isotopes [83, 84]. Specifically, the ${ }^{53} \mathrm{Cr} /{ }^{52} \mathrm{Cr}$ ratio increases with increased reduction, as the lighter isotope is preferentially reduced by reductants such as magnetite [83]. Fractionation is measured using the parameter \%o, where the ratio ${ }^{53} \mathrm{Cr} /{ }^{52} \mathrm{Cr}$ of the NIST standard 979 (a chromium nitrate salt) is $0.11339 \pm 0.00015 \%$. Reduction of $\mathrm{Cr}(\mathrm{VI})$ has been observed to cause an increase in the $\delta^{53}$ value from $0 \%$, which is considered the average of the Earth's crust, to values between 1.1 and $5.8 \%$ observed in groundwater plumes [11, 84]. Conversely, studies by Zink et al. [85] indicated that oxidation 
of $\mathrm{Cr}(\mathrm{III})$ to $\mathrm{Cr}(\mathrm{VI})$ did not result in substantial isotopic fractionation. Sorption of $\mathrm{Cr}(\mathrm{VI})$ on mineral surfaces does not produce substantial fractionation either [86].

Farkaš et al. [87] observed that even though the average $\delta 53$ value in chromites around the world is $-0.079 \%$, substantial increase was observed with increased alteration and serpentinization of ultramafic rocks, reaching a maximum value of $1.219 \%$. The authors theorized that this may be related to contact of produced $\mathrm{Cr}(\mathrm{VI})$ with magmatic $\mathrm{Fe}(\mathrm{II})$ during alteration and serpentinization. This observation is important in evaluating field data from ultramafic regions, since the base $\delta^{53}$ value may be different than the commonly assumed $0 \%$ o of the Earth's crust. Izbicki et al. [11] investigated $\mathrm{Cr}$ isotope ratios in a geogenic Cr plume in Mojave Desert and observed that while the $\delta^{53}$ value was not by itself diagnostic of anthropogenic vs. geogenic origin, it was possible to evaluate the anthropogenic input by combining the isotope data with oxygen and deuterium isotope, as well as major ion data.

\section{Outlook and Knowledge Gaps}

Natural occurrence of hexavalent chromium in natural waters and especially groundwater is a potential public health concern in several areas globally, given that the observed concentrations often exceed $10 \mu \mathrm{g} / \mathrm{L}$, the current standard in the state of California, and some cases even $50 \mu \mathrm{g} / \mathrm{L}$, the suggested maximum contaminant level by the World Health Organization for total $\mathrm{Cr}$. While policy on the regulation of $\mathrm{Cr}(\mathrm{VI})$ and total $\mathrm{Cr}$ in drinking water remains inconsistent, the current state of knowledge clearly dictates that hazardous levels of $\mathrm{Cr}$ may be produced in aqueous environments with ultramafic geologic backgrounds, under favorable geochemical conditions. The surveyed literature indicates that alkaline $(\mathrm{pH}>8)$ and oxic environments are favorable for enhanced $\mathrm{Cr}(\mathrm{VI})$ mobilization, as these conditions minimize competing immobilization processes, i.e., sorption and reduction, both of which are favored by more acidic $\mathrm{pH}$, and reduction is correlated with anaerobic and anoxic conditions. The genesis of $\mathrm{Cr}(\mathrm{VI})$ from the rock, sediment, or soil involves an oxidation step, given that $\mathrm{Cr}$ is exclusively present as $\mathrm{Cr}$ (III) in the various minerals comprising the solid phase. These minerals include chromite, which appears to be the most important host for $\mathrm{Cr}$ (III) on a mass basis, followed by chlorite, $\mathrm{Fe}-\mathrm{Cr}$ oxyhydroxides and clays that are formed as a result of weathering processes. $\mathrm{Cr}$ (III) released by these minerals upon weathering and dissolution is available to participate in redox reactions. Oxidation has been thought to be primarily driven by high-valence Mn oxides (birnessite, pyrolusite, and others), but recent analyses indicate that metastable hydrogen peroxide may also be an important oxidant in the subsurface. The role of dissolved oxygen remains unclear, even though the available studies indicate that this mechanism is too slow to produce substantial levels of $\mathrm{Cr}(\mathrm{VI})$ in groundwater.
Dissolved oxygen may be important to drive oxidation of dissolved $\mathrm{Mn}$ (II) that can precipitate on $\mathrm{Cr}$ (III)-bearing solids as birnessite and drive solid-solid $\mathrm{Cr}$ oxidation.

Despite the understanding of the speciation of $\mathrm{Cr}$ in natural geological settings, as well as the general mechanisms of oxidation and release, there are still several unanswered questions to address. The most important of these are the following:

- To what extent are oxidation mechanisms active over time, as the surface of the participating minerals is passivated and how can the groundwater levels of $\mathrm{Cr}(\mathrm{VI})$ be predicted as a function of geochemical conditions?

- At what rate is $\mathrm{Cr}(\mathrm{VI})$ produced in productive aquifers today and what is the influence of the measured concentrations on the quality of irrigation water and the impacted crops in agricultural areas?

- What is the impact of agricultural and other anthropogenic activities on the background levels of $\mathrm{Cr}$ in different areas around the world?

Additional research is necessary to address the aforementioned issues, both at the fundamental level (e.g., to further investigate oxidation mechanisms) as well as at a larger scope to assess the feedback between agricultural activity and $\mathrm{Cr}$ levels in groundwater, soil, and crops.

Acknowledgments The authors would like to thank T. Mpouras, $\mathrm{PhD}$ candidate (NTUA), for the substantial help in data compiling and processing. This study was supported by the LIFE+ CHARM project (LIFE10 ENV/GR/000601) and the Marie Curie project SPECHROM (no. 299392).

\section{Compliance with Ethical Standards}

Conflict of Interest On behalf of all authors, the corresponding author states that there is no conflict of interest.

Human and Animal Rights and Informed Consent The article does not contain any studies with human or animal subjects performed by any of the authors.

\section{References}

Papers of particular interest, published recently, have been highlighted as:

- Of importance

•- Of importance

1. Saha R, Nandi R, Saha B. Review: sources and toxicity of hexavalent chromium. J Coord Chem. 2011;64(10):1782-806.

2. Oze C, Fendorf S, Bird KD, Coleman GR. Chromium geochemistry of serpentine soils. Int Geol Rev. 2004;46:97-126. 
3. Bulmer CE, Lavkulich LM. Pedogenic and geochemical processes of ultramafic soils along a climatic gradient in southwestern BritishColumbia. Can J Soil Sci. 1994;74:165-77.

4. Fantoni D, Brozzo G, Canepa M, Cipolli F, Marini L, Ottonello G, Zuccolini MV. Natural hexavalent chromium in groundwaters interacting with ophiolitic rocks. Environ Geo. 2002;42:871-82.

5. Becquer T, Quantin C, Rotte-Capet S, Ghanbaja J, Mustin C, Herbillon AJ. Sources of trace metals in Ferralsols in New Caledonia. Eur J Soil Sci. 2006;57:200-13.

6. Kierczak J, Neel C, Bril H, Puziewicz J. Effect of mineralogy and pedoclimatic variations on $\mathrm{Ni}$ and $\mathrm{Cr}$ distribution in serpentine soils under temperate climate. Geoderma. 2007;142:165-77.

7. Dermatas D, Mpouras A, Chrysochoou M, Vatseris C, Papassiopi N, Xenidis A, Theologou E, Bompoti N. Origin and concentration profile of chromium in a Greek aquifer. J Hazard Mater. 2015;281:35-46.

8. Garnier J, Quantin C, Martins ES, Becquer T. Solid speciation and availability of chromium in ultramafic soils from Niquelândia, Brazil. J Geochem Explor. 2006;88:206-9.

9. Dzemua GL, Mees F, Stoops G, Van Ranst E. Micromorphology, mineralogy and geochemistry of lateritic weathering over serpentinite in south-east Cameroon. J Afr Earth Sci. 2011;60:38-48.

10. Hseu ZY. Concentration and distribution of chromium and nickel fractions along a serpentinitic toposequence. Soil Sci. 2006;171: 341-53.

11. Izbicki JA, Bullen TD, Martin P, Schroth B. Delta chromium-53/52 isotopic composition of native and contaminated groundwater, Mojave Desert, USA. Appl Geochem. 2012;27:841-53.

12. A. Villalobos-Aragon, A.S. Ellis, M.A. Armienta, O. Morton, T.M. Johnson, J.J. Glessner, Chromium contamination in Leon Valley Mexico: insights from chromium stable isotope, Am. Geophys. Union Fall Meeting (2008) abstract.

13. Kierczak J, Neel C, Aleksander-Kwaterczak U, Helios-Rybicka E, Bril a H, Puziewicz J. Solid speciation and mobility of potentially toxic elements from natural and contaminated soils: a combined approach. Chemosphere. 2008;73:776-84.

14. Panagiotakis I, Dermatas D, Vatseris C, Chrysochoou M, Papassiopi N, Xenidis A, Vaxevanidou K. Forensic investigation of a chromium(VI) groundwater plume in Thiva. Greece, Journal of Hazardous Materials. 2015;281:27-34.

15. Newman D. A case of adeno-carcinoma of the left inferior turbinated body and perforation of the nasal septum in the person of a worker in chrome pigments. Glasgow Med J. 1890;33:469-70.

16. CalEPA OEHHA, Public health goal for hexavalent chromium $(\mathrm{Cr}$ VI) in drinking water, California Environmental Protection Agency, Office of Environmental Health Hazard Assessment, 2011, (http://www.oehha.org/water/phg/072911Cr6PHG.html).

17. Megremi I. Distribution and bioavailability of $\mathrm{Cr}$ in central Euboea, Greece. Cent Eur J Geosci. 2010;2(2):103-23.

18. Ball JW, Izbicki JA. Occurrence of hexavalent chromium in ground water in the western Mojave Desert, California. Appl Geochem. 2004;19:1123-35.

19. Margiotta S, Mongelli G, Summa V, Paternoster M, Fiore S. Trace element distribution and $\mathrm{Cr}(\mathrm{VI})$ speciation in $\mathrm{Ca}-\mathrm{HCO} 3$ and $\mathrm{Mg}$ $\mathrm{HCO} 3$ spring waters from the northern sector of the Pollino massif, southern Italy. J Geochem Explor. 2012;115:1-12.

20. Lelli M, Grassi S, Amadori M, Francescini F. Natural Cr(VI) contamination of groundwater in the Cecina coastal area and its inner sectors (Tuscany, Italy). Environ Earth Sci. 2014;71:3907-19.

21. Apollaro C, Marini L, Critelli T, Barca D, Bloise A, De Rosa R, Liberi F, Miriello D. Investigation of rock-to-water release and fate of major, minor, and trace elements in the metabasalt-serpentinite shallow aquifer of Mt. Reventino (CZ, Italy) by reaction path modelling. Appl Geochem. 2011; Volume 26(Issues 9-10):1722-40.

22. Dermatas D, Vatseris C, Panagiotakis I, Chrysochoou M. Potential contribution of geogenic chromium in groundwater contamination of a Greek heavily industrialized area. Chem Eng Trans. 2012;28: 217-22.

23. Eliopoulos M, Megremi I, Vasilatos C. Factors controlling the heterogeneous distribution of $\mathrm{Cr}(\mathrm{VI})$ in soil, plants and groundwater: evidence from the Assopos basin, Greece. Chem Erde. 2011;71:39 52.

24. Moraetis D, Nikolaidis NP, Karatzas GP, Dokou Z, Kalogerakis N, Winkel LHE, Palaiogianni-Bellou A. Origin and mobility of hexavalent chromium in north-eastern Attica, Greece. Appl Geochem. 2012;27:1170-8.

25. Tziritis E, Kelepertzis E, Korres G, Perivolaris D, Repani S. Hexavalent chromium contamination in groundwaters of Thiva basin, Central Greece. Bull Environ Contam Toxicol. 2012;89:1073-7.

26. Stamatis G, Alexakis D, Gamvroula D, Migiros G. Groundwater quality assessment in Oropos-Kalamos basin, Attica, Greece. Environ Earth Sci. 2011;64:973-88.

27. Vasilatos C, Megremi I, Economou-Eliopoulos M, Mitsis I. Hexavalent chromium and other toxic elements in natural waters in the Thiva-Tanagra-Malakasa basin, Greece. Hellen J Geosci. 2008;43:57-66.

28. Gonzalez AR, Ndung'u K, Flegal AR. Natural occurrence of hexavalent chromium in the aromas Red Sands aquifer, California. Environ. Sci. Technol. 2005;39(15):5505-11.

29. Mills CT, Morrison JM, Goldhaber MB, Ellefsen KJ. Chromium(VI) generation in vadose zone soils and alluvial sediments of the southwestern Sacramento Valley, California: a potential source of geogenic $\mathrm{Cr}(\mathrm{VI})$ to groundwater. Appl Geochem. 2011;26:1488-501.

30. Manning AH, Mills CT, Morrison JM, Ball LB. Insights into controls on hexavalent chromium in groundwater provided by environmental tracers, Sacramento Valley, California, USA, applied. Geochemistry. 2015;Volume 62:186-99. Useful study on environmental tracers related to $\mathrm{Cr}(\mathrm{VI})$

31. $\bullet$ McClain CN, Maher K. Chromium fluxes and speciation in ultramafic catchments and global rivers. Chem Geol. 2016; Volume 426: 135-57. Important overview of the geochemistry of $\mathrm{Cr}$ in ultramafic environments and detailed calculation of fluxes

32. Robles-Camacho J, Armienta MA. Natural chromium contamination of groundwater at León Valley, México. J Geochem Explor. 2000;68:167-81.

33. Bertolo R, Bourotte C, Marcolan L, Oliveira S, Hirata R. Anomalous content of chromium in a cretaceous sandstone aquifer of the Bauru basin, state of São Paulo, Brazil. J S Am Earth Sci. 2011;31:69-80.

34. B. A. Roberts and J. Proctor (eds), The ecology of areas with serpentinized rocks, Kluwer Academic Publishers, 1992.

35. B.J. Alloway, Heavy metals in soils, third ed., trace metals and metalloids in soils and their bioavailability, Environmental Pollution (22), 2013.

36. Deschamps F, Godard M, Guillot S, Hattori K. Geochemistry of subduction zone serpentinites: a review. Litho. 2013;178:96-127.

37. Fandeur D, Juillot F, Morin G, Olivi L, Cognigni A, Ambrosi JP, Guyot F, Fritsch E. Synchrotron-based speciation of chromium in an Oxisol from New Caledonia: importance of secondary Feoxyhydroxides. Am Mineral. 2009;94:710-9.

38. D'Amico M, Julitta F, Previtali F, Cantelli D. Podzolization over ophiolitic materials in the western alps (Natural Park of Mont Avic, Aosta Valley, Italy). Geoderma. 2008;146:129-37.

39. Gunia P. The petrology and geochemistry of mantle-derived basic and ultrabasic rocks from the Szklary massif in the fore-Sudetic block (SW Poland). Geol Sudetica. 2000;33:71-83.

40. Izbicki JA, Ball JW, Bullen TD, Sutley SJ. Chromium, chromium isotopes and selected trace elements, western Mojave Desert, USA. Appl Geochem. 2008;23:1325-52.

41. Bertolo R, Bourotte C, Marcolan L, Oliveira S, Hirata R. Anomalous content of chromium in a cretaceous sandstone aquifer 
of the Bauru basin, state of São Paulo, Brazil. J S Am Earth Sci. 2011;31:69-80.

42. Rajapashka AU, Vithanage M, Oze C, Bandara W, Weerasooriya R. Nickel and manganese release in serpentine soil from the Ussangoda ultramafic complex. Sri Lanka, Geoderma. 2012;189-190:1-9.

43. Vithanage M, Rajapaksha AU, Oze C, Nishanta Rajakaruna CB. Dissanayake, metal release from serpentine soils in Sri Lanka. Environ Monit Assess. 2014;186(6):3415-29.

44. Trolard F, Bourrie G, Jeanroy E, Herbillon AJ, Martin H. Trace metals in natural iron oxides from laterites: a study using selective kinetic extraction. Geochim. Cosmochim. Ac. 1995;59(7):1285-97.

45. Caillaud J, Proust D, Philippe S, Fontaine C, Fialin M. Trace metals distribution from a serpentinite weathering at the scales of the weathering profile and its related weathering microsystems and clay minerals. Geoderma. 2009;149:199-208.

46. Cheng CH, Jien SH, Lizuka Y, Tsai H, Chang YH, Hseu ZY. Pedogenic chromium and nickel partitioning in serpentine soils along a toposequence. Soil Sci. Soc. Am. 2011;75:659-68.

47. Bonifacio E, Zanini E, Boero V, Franchini-Angela M. Pedogenesis in a soil catena on serpentinite in North-Western Italy. Geoderma. 1997;75:33-51.

48. Morrison JM, Goldhaber MB, Lee L, Holloway JM, Wanty RB, Wolf RE, Ranville JF. A regional-scale study of chromium and nickel in soils of northern California, USA. Appl Geochem. 2009;24:1500-11.

49. Morrison JM, Goldhaber MB, Mills CT, Breit GN, Hooper RL, Holloway JAM, Diehl SF, Ranville JF. Weathering and transport of chromium and nickel from serpentinite in the coast range ophiolite to the Sacramento Valley. California, USA, Applied Geochemistry, Volume. 2015;61:72-86.

50. Burkhard DJM. Accessory chromium spinels: their coexistence and alteration in serpentinites. Geochim. Cosmochim. Ac. 1992;37: 1297-306.

51. Oze C, Fendorf S, Bird KD, Coleman GR. Chromium geochemistry in serpentinized ultramafic rocks and serpentine soils from the Franciscan complex of California. Am J Sci. 2004;304:67-101.

52. Kelepertzis E, Galanos E, Mitsis I. Origin, mineral speciation and geochemical baseline mapping of $\mathrm{Ni}$ and $\mathrm{Cr}$ in agricultural topsoils of Thiva Valley (Central Greece). J Geochem Explor. 2013;125:56-68.

53. Hseu Z-Y, Zehetner F, Ottner F, Iizuka Y. Clay-mineral transformations and heavy-metal release in Paddy soils formed on serpentinites in eastern Taiwan. Clay Clay Miner. 2015; Volume 63(13) :119-31.Number 2

54. Quantin C, Ettler V, Garnier J, Šebek O. Sources and extractability of chromium and nickel in soil profiles developed on Czech serpentinites. Compt Rendus Geosci. 2008;340:872-82.

55. Economou-Eliopoulos M, Megremi I, Vasilatos C. Factors controlling the heterogeneous distribution of $\mathrm{Cr}(\mathrm{VI})$ in soil, plants and groundwater: evidence from the Assopos basin, Greece. Chem Erde. 2011;71:39-52.

56. Caillaud J, Proust D, Righi D. Weathering sequences of rockforming minerals in a serpentinite: influence of microsystems on clay mineralogy. Clay Clay Miner. 2006;54(1):87-100.

57. Lee BD, Sears SK, Graham RC, Amrhein C, Vali H. Secondary mineral genesis from chlorite and serpentine in an ultramafic soil toposequence. Soil Sci Soc Am J. 2003;67:1309-17.

58. Bulmer CE, Lavkulich LM. Pedogenic and geochemical processes of ultramafic soils along a climatic gradient in southwestern BritishColumbia. Can J Soil Sci. 1994;74:165-77.

59. Yongue-Fouateu R, Yemefack M, Wouatong ASL, Ndjigui PD, Bilong P. Contrasted mineralogical composition of the laterite cover on serpentinites of Nkamouna-Kongo, Southeast Cameroon. Clay Miner. 2009;44:221-37.

60. Cheng $\mathrm{CH}$, Jien SH, Lizuka Y, Tsai H, Chang YH, Hseu ZY. Pedogenic chromium and nickel partitioning in serpentine soils along a toposequence. Soil Sci Soc Am. 2011;75:659-68.
61. Sokol EV, Gaskova OL, Kokh SN, Kozmenko OA, Seryotkin YV, Vapnik Y, Murashko MN. Chromatite and its $\mathrm{Cr}^{3+}$ - and $\mathrm{Cr}^{6+}$-bearing precursor minerals from the Nabi Musa mottled zone complex, Judean Desert. Am Mineral. 2011;96:659-74.

62. Burns VM, Burns RG. Mineralogy of chromium. Geochim. Cosmochim. Ac. 1975;39(6-7):903-10.

63. Eckhardt, F.-J., Heimbach, W. Ein natürliches Vorkommen von CaCrO4 (Chromatit) (1963) Die Naturwissenschaften, 50 (19), p. 612.

64. Bulmer CE, Lavkulich LM, Schreier HE. Morphology, chemistry, and mineralogy of soils derived from serpentinite and tephra in southwestern British Columbia. Soil Sci. 1992;154(1):72-82.

65. Welch SA, Banfield JF. Modification of olivine surface morphology and reactivity by microbial activity during chemical weathering. Geochim. Cosmochim. Ac. 2002;66(2):213-21.

66. Kierczak J, Pędziwiatr A, Waroszewski J, Modelska M. Mobility of $\mathrm{Ni}$. $\mathrm{Cr}$ and $\mathrm{Co}$ in serpentine soils derived on various ultrabasic bedrocks under temperate climate, Geoderma, Volume. 2016;268(15):78-91.

67. Wilson MJ, Jones D, McHardy WJ. The weathering of serpentinite by Lecanora Atra. Lichenologist. 1981;13(2):167-76.

68. Mills CT, Goldhaber MB. Laboratory investigations of the effects of nitrification-induced acidification on $\mathrm{Cr}$ cycling in vadose zone material partially derived from ultramafic rocks. Sci Total Environ. 2012;435-436:363-73.

69. J.P. Gustafsson, Visual MINTEQ ver. 3.0. 2010, Available at: http://www2.lwr.kth.se/English/OurSoftware/vminteq/index.htm [Verified: July 2016].

70. Saputro S, Yoshimura K, Matsuoka S, Takehara K, Narsito AJ, Tennichi Y. Speciation of dissolved chromium and the mechanisms controlling its concentration in natural water. Chem Geol. 2014;364:33-41.

71. Fandeur D, Juillot F, Morin G, Olivi L, Cognigni A, Webb SM, Ambrosi JP, Fritsch E, Guyot F, Brown Jr GE. XANES evidence for oxidation of $\mathrm{Cr}(\mathrm{III})$ to $\mathrm{Cr}(\mathrm{VI})$ by Mn-oxides in a lateritic regolith developed on serpentinized ultramafic rocks of New Caledonia. Environ. Sci. Technol. 2009;43:7384-90.

72. Fendorf SE, Zasoski RJ. Chromium(III) oxidation by $\delta-\mathrm{MnO}_{2} .1$. Characterization. Env Sci Technol. 1992;26:79-85.

73. Eary LE, Rai D. Kinetics of chromium(III) oxidation to chromium(VI) by reaction with manganese dioxide. Env Sci Technol. 1987;21:1187-93.

74. Cooper GRC. Oxidation and toxicity of chromium in ultramafic soils in Zimbabwe. Appl Geochem. 2002;17:981-6.

75. Manceau A, Charlet L. X-ray absorption spectroscopic study of the sorption of $\mathrm{Cr}(\mathrm{III})$ at the oxide/water interface. I molecular mechanism of $\mathrm{Cr}(\mathrm{III})$ oxidation on Mn oxides. J Colloid Interf Sci. 1992;148(2):425-42.

76. Oze C, Bird KD, Fendorf S. Genesis of hexavalent chromium from natural sources in soil and groundwater. Proc Natl Acad Sci U S A. 2007;104(16):6544-9.

77. Rajapaksha AU, Vithanage M, Sik Ok Y, Oze C. Cr(VI) formation related to $\mathrm{Cr}$ (III)-muscovite and birnessite interactions in ultramafic environments. Environ. Sci. Technol. 2013;47:9722-9.

78. Gustafsson JP, Persson I, Oromieh AG, van Schaik JWJ, Sjostedt C, Kleja DB. Chromium(III) complexation to natural organic matter: mechanisms and modeling. Environ. Sci. Technol. 2014;48:1753-61.

79: Namgung S, Kwon M-J, Qafoku NP, Lee G. Cr(OH)3(s) oxidation induced by surface catalyzed $\mathrm{Mn}$ (II) oxidation. Environ Sci Technol. 2014;48:10760-8. This is the only study that shows oxidation of solid $\mathrm{Cr}(\mathrm{OH}) 3$ by $\mathrm{Mn}$ oxides

80. Rai D, Zachara JM, Eary LE, Girvin DC, Moore DA, Resch CT, Sass BM, Schmidt RL. Geochemical behavior of chromium species, interim report Electric Power Research Institute (EPRI) EA EA-4544. Palo Alto, CA: EPRI; 1986. 
81.• C. Oze, N. Sleep, R.G. Coleman and S. Fendorf, Anoxic oxidation of chromium, Geology in press (2016) DOI: 10.1130/G37844.1. This is the first study that points to $\mathrm{H2O}$ as important oxidant in ultramafic environments.

82. Fendorf SE. Surface reactions of chromium in soils and waters. Geoderma. 1995;67:55-71.

83. Ellis AS, Johnson TM, Bullen TD. Cr isotopes and the fate of hexavalent chromium in the environment. Science. 2002;295: 2060-2.

84. Berna E, Johnson TM, Makdisi RS, Basu A. Cr stable isotopes as indicators of $\mathrm{Cr}(\mathrm{VI})$ reduction in groundwater: a detailed timeseries study of a point-source plume. Environ Sci Technol. 2010;44:1043-8.
85. Zink S, Schoenberg R, Staubwasser M. Isotopic fractionation and reaction kinetics between $\mathrm{Cr}(\mathrm{III})$ and $\mathrm{Cr}(\mathrm{VI})$ in aqueous media. Geochim. Cosmochim. Ac. 2010;74:5729-45.

86. Ellis AS, Johnson TM, Bullen TD. Using chromium stable isotope ratios to quantify $\mathrm{Cr}(\mathrm{VI})$ reduction: lack of sorption effects. Environ. Sci. Technol. 2004;38:3604-7.

87. Farkas J, Chrastny V, Novák M, Cadkova E, Pasava J, Chakrabarti $\mathrm{R}$, Jacobsen SB, Ackerman L, Bullen TD. Chromium isotope variations $(\delta 53 / 52 \mathrm{Cr})$ in mantle-derived sources and their weathering products: implications for environmental studies and the evolution of $\delta 53 / 52 \mathrm{Cr}$ in the Earth's mantle over geologic time. Geochim Cosmochim Ac. 2013;123:74-92. 